\title{
ILCEA
}

Revue de l'Institut des langues et cultures

d'Europe, Amérique, Afrique, Asie et Australie

43 | 2021

Images des Amériques : fabrique, représentations, usages

\section{El cine y la representación de la historia latinoamericana en la película También la lluvia (Icíar Bollaín, 2010)}

Le cinéma et la représentation de l'histoire latino-américaine dans le film

También la lluvia [Même la pluie en français] (Icíar Bollain, 2010)

Cinema and Representation of America Latina's History in the Film También la lluvia [Even the Rain in English] (Icíar Bollaín, 2010)

\section{Mariana Piccinelli}

\section{OpenEdition}

Journals

Edición electrónica

URL: https://journals.openedition.org/ilcea/13478

DOI: 10.4000/ilcea.13478

ISSN: 2101-0609

Editor

UGA Éditions/Université Grenoble Alpes

Edición impresa

ISBN: 978-2-37747-299-4

ISSN: $1639-6073$

\section{Referencia electrónica}

Mariana Piccinelli, «El cine y la representación de la historia latinoamericana en la película También la Iluvia (Icíar Bollaín, 2010)», ILCEA [En línea], 43 | 2021, Publicado el 30 junio 2021, consultado el 30 junio 2021. URL: http://journals.openedition.org/ilcea/13478 ; DOI: https://doi.org/10.4000/ilcea. 13478

Este documento fue generado automáticamente el 30 junio 2021.

(C) ILCEA 


\title{
El cine y la representación de la historia latinoamericana en la película También la lluvia (Icíar Bollaín, 2010)
}

\author{
Le cinéma et la représentation de l'histoire latino-américaine dans le film \\ También la lluvia [Même la pluie en français] (Icíar Bollain, 2010) \\ Cinema and Representation of America Latina's History in the Film También la \\ lluvia [Even the Rain in English] (Icíar Bollaín, 2010)
}

\section{Mariana Piccinelli}

\section{1. ¿Cómo filmar la llegada de Cristóbal Colón a América desde el presente?}

1 En el año 2010 la actriz, directora y guionista ibérica Icíar Bollain dio a conocer su obra También la lluvia. En ella se cuenta la historia de un cineasta español y su productor, quienes en su intento de filmar una película sobre Cristóbal Colón en América, arriban a Cochabamba (Bolivia) en el preciso momento en el que se desata la llamada Guerra del Agua, durante los meses de enero a abril del año $2000^{1}$. La elección del lugar, que no tiene nada que ver con las Antillas (donde efectivamente llegaron los primeros barcos europeos), da pie a un interesante debate sobre la conformación del indígena latinoamericano y su representación, tanto en el siglo xv como en el xxI. Ahora bien, el proceso de filmación que se representa en la película, no sólo está signado por una visión estereotipada de los españoles sobre América Latina, sino también por un proceso revolucionario que se acelera rápidamente y obliga a los extranjeros a tomar posiciones extremas en relación al mismo.

2 También la lluvia es una película sobre cómo hacer una película: es una representación que muestra el proceso de elaboración de una recreación cinematográfica; pero 
también es una obra que une procesos críticos, violentos y opresivos mediante la narración doble de hechos pasados lejanos y más recientes. La naturaleza compleja de este largometraje permite un análisis múltiple (todo film lo amerita, pero este aún más) tanto en relación a la forma en la que está construida la historia (o las historias) como al contenido con el que trabaja. Al respecto, Bonnie O. Thornton se pregunta cómo analizar esta película, desde qué perspectiva se la puede examinar y cómo debe relatar su trama para estudiarla. Por eso, si bien empieza describiendo la situación que llevó al desarrollo de la Guerra del Agua en el año 2000, al avanzar en su análisis se cuestiona «¿Es entonces el tema la Guerra del Agua? ¿La historia de un filme? ¿La historia de una historia?» (Thornton, 2015: 3).

Dice Sabine Schlickers que esta película:

Reúne varios géneros que se entrelazan a modo de juegos de espejo, denunciando sutilmente la explotación de las culturas indígenas desde su "descubrimiento" hasta la actualidad, no solo por parte de los opresores de siempre, en este caso el FMI, que era el responsable de la privatización del agua en Bolivia, sino incluso por parte de aquellos que tienen las mejores intenciones, en este caso los miembros del equipo fílmico. (2015: 118)

Su definición en este caso es más temática que formal. Para ella la obra tiene un hilo conductor, que es la explotación -ayer, hoy y siempre- de los pueblos originarios bolivianos en manos de opresores extranjeros, sin importar cuales fuesen sus intenciones originales. Pensando en un análisis de tipo ético o moral, más allá de la temática que toca la película, es interesante ver la evolución que tienen los personajes centrales y la reacción que tiene cada uno frente a un conflicto apremiante e inminente, en contraste con sus prenociones o sus acciones previas al desarrollo del problema. Así, podríamos seguir por un largo tiempo apuntando distintas formas de análisis posible. ¿Qué ejes elegimos entonces para tratar en el presente trabajo?

Como historiadores esta cinta nos resulta interesante en varias maneras. Primero, porque desde la trama de la película se plantea la recreación de un hecho pasado lejano (la llegada de Colón a América) ${ }^{2}$, que a su vez se inserta dentro de la representación de un proceso histórico más reciente (la Guerra del Agua en Cochabamba). Segundo, porque ambas representaciones se entrelazan dando lugar a una reinterpretación de los hechos desde el presente. Y finalmente, porque esta operación le otorga a la obra cinematográfica un papel activo en la revisión de la historia latinoamericana. Lo que aquí nos interesa, entonces, es estudiar el discurso histórico que se proyecta en el film, las formas que adopta y sus implicancias. También, la película sirve para analizar el discurso histórico que se narra en relación con un presente concreto, que puede evaluar y poner en juego las consecuencias de procesos pasados. En este sentido, que el largometraje haya sido elaborado por una directora española y de tradición altamente combativa a la hora de plantear sus temáticas, creemos, enriquece y complejiza el análisis.

\section{Una película sobre cómo hacer una película}

6 También la lluvia es el quinto largometraje de la directora y actriz Icíar Bollaín. De coproducción española, francesa y mexicana, cuenta con el guión del renombrado Paul Laverty y las actuaciones de Luis Tosar, Gael García Bernal y Juan Carlos Aduviri. Fue filmado enteramente en Bolivia, dividiendo el rodaje entre la selva del Chapare y la Ciudad de Cochabamba. La película narra la historia del cineasta Sebastián (Gael García 
Bernal) y su productor Costa (Luis Tosar), quienes en el año 2000 deciden realizar un film sobre la conquista y la llegada de Cristóbal Colón a América. La mano de obra barata boliviana y los deseos de Sebastián de hacer una obra grandilocuente llevan al equipo de filmación a Bolivia, para realizar sus tomas de exteriores. La película de Bollaín comienza entonces en la ciudad de Cochabamba, donde cientos de bolivianos hacen cola para participar en el casting abierto solicitado por Sebastián, y en el cual productor y director esperan dar con el actor protagonista de la obra que van a hacer. Sebastián encuentra al líder-héroe de su proyecto en Daniel, uno de los tantos que están en la fila esperando su oportunidad. Daniel destaca del resto por su belicosidad y determinación, características que encantan al director, ya que lo considera perfecto para hacer el papel de Hatuey, el líder de la rebelión taína en su film sobre la conquista.

El guión del proyecto de Sebastián comienza con la llegada de Colón a las Antillas y la exigencia de entregar oro como impuestos a los españoles; continúa con el maltrato que éstos propician a los indios taínos, la defensa del sacerdote Antonio de Montesinos a los oprimidos y termina con una revuelta taína liderada por Hatuey, sofocada por los colonizadores con encarnizada violencia. En paralelo, mientras se ensayan y filman esas escenas, en la Cochabamba actual los habitantes más pobres se están quedando sin agua. Explican que compraron un pozo y deben cavar siete kilómetros de zanjas para que les llegue el agua a sus hogares. Al respecto, comenta la historiadora Bonnie Thornton:

En 2000, en Bolivia, la Guerra del Agua surgió a causa de las políticas y problemas que acompañan a la globalización. Bechtel, una empresa internacional, hizo un contrato transnacional con el gobierno de Bolivia para gestionar los sistemas y distribución del agua de la región. Antes de la llegada de esta empresa, el control del agua era público, dirigido por grupos indígenas. La privatización del agua por el gobierno instigó protestas violentas durante las cuales los grupos indígenas bloquearon las calles y puentes a Cochabamba, y el ejército intervino utilizando fuerza para manejar la situación. Acabaron con mucha gente herida o muerta. (2015: 2)

En consonancia con esta pequeña explicación de la Guerra del Agua, el conflicto en el film de Bollaín comienza cuando los agentes de gobierno quieren cerrar los pozos que recogen el agua de lluvia y destruir el trabajo que los pobladores del cerro hicieron para conseguir ese recurso natural básico. El primer enfrentamiento es entre la policía y las mujeres, pero se aviva aún más con una protesta liderada por Daniel, quien denuncia la venta de recursos ambientales como los lagos y la prohibición de recoger agua de lluvia, en favor de compañías británicas y estadounidenses. A esto le sigue una asamblea de todo el barrio afectado, donde se discute la necesidad de ir a una marcha para reclamar por el agua y se presentan argumentos a favor y en contra. La asamblea decide finalmente acudir a la enorme manifestación que se realiza al día siguiente en la plaza principal. Mientras, en el edificio colindante a la plaza, el equipo entero de filmación es recibido con champagne por el Gobernador de la ciudad. Como antes, Daniel lidera la manifestación y su encarcelamiento pone en peligro la realización de la película.

9 En un principio la violencia del presente de la película de Bollaín se asemeja a la crueldad representada en las escenas de la obra de Sebastián, pero a medida que avanza la historia la pelea por el agua se recrudece, acelera y desborda, arrasándolo todo y subsumiendo la filmación extranjera en los apremiantes acontecimientos de la Guerra del Agua cochabambina. De nada sirven los sobornos pagados a la policía, en cuanto 
Daniel sale del calabozo la ciudad entera estalla y los españoles deben huir de Bolivia, ya que se encuentran en abierto peligro.

10 El golpe de realidad apremiante que la Guerra impone a los extranjeros, encuentra a Sebastián y a Costa en posiciones enfrentadas, no solo entre ellos, sino consigo mismos. En un principio el director parecía sensible a la situación de los quechuas (tanto como lo era con el sufrimiento taíno en las épocas de Colón). Así, promete que todos sus actores serán tratados de la mejor manera y se enfrenta al gobernador cuando habla mal de los manifestantes en la plaza. Sin embargo, la imposibilidad de filmar la escena principal de su obra tras fallidos intentos lo vuelve egoísta, ensimismado y poco sensible ante la realidad (esa realidad a la que le juró fidelidad cuando escribió su guión), al punto de gritar «donde chingados están mis indígenas» ${ }^{3}$ en el medio de la filmación.

11 En este juego de espejos que es la película, Costa realiza el camino contrario: pragmático e indiferente con la situación de los quechuas, fastidiado por las molestias que el compromiso con la revuelta de su protagonista principal le pueda traer, no duda en menospreciar a su mano de obra o sobornar a Daniel para que se mantenga al margen de los problemas. A medida que crece el conflicto y gracias a la relación que establece con Daniel y su familia, resulta ser el más involucrado de todo el equipo, y antes de irse de Cochabamba logra asistirlos en medio de un enfrentamiento violento. Claro que esta ayuda parece insuficiente frente a la situación en la que quedan los miles de cochabambinos, pero en relación al personaje de Costa, su accionar es muchísimo más comprometido que lo que mostraba al comienzo; en él, la Guerra del Agua y su tiempo en Bolivia han operado un cambio significativo.

\section{3. ¿Cómo contar hechos pasados a través del cine?}

12 Desde sus orígenes el medio audiovisual ha abierto numerosas posibilidades de expresión y comunicación entre los cineastas y sus espectadores. Como producto cultural, es claramente manifestación de la comunidad que lo crea y a la vez una poderosa herramienta de intervención social, ya que contribuye a la transmisión, reproducción (pero también a la reelaboración) de ideas, pautas y valores compartidos ${ }^{4}$. Esta doble naturaleza obliga a considerarlo no sólo como un documento artísticocultural que posee las huellas de la colectividad de la que emana, sino también como discurso destinado a tener algún impacto entre los que lo reciben. Una película, entonces, puede ser entendida como arte pero a la vez como un texto que posee pautas o códigos sociales que adquieren sentido al ser reconocidos por el espectador ${ }^{5}$.

13 Como historiadores, esta proposición tiene fuertes implicancias: al considerar un audiovisual como un texto, debemos entender que cuando este representa hechos del pasado, lo que se evidencia en la pantalla es en esencia un discurso histórico. Como tal, (y pensando en la importancia, vitalidad e influencia que posee el medio audiovisual) entra en relación con otros discursos históricos que se plantean desde el campo intelectual y que en general se manifiestan a través de la escritura. En definitiva, al elaborar un film histórico los cineastas se basan en bibliografía específica producida en la Academia, o consultan especialistas para elaborar sus guiones y caracterizar a los personajes ${ }^{6}$. A veces, el discurso histórico filmado está en consonancia con el escrito y ciertas cintas contribuyen a difundir y potenciar nociones que ya están instaladas en la sociedad ${ }^{7}$. Otras, los audiovisuales pueden plantear críticas 
o actualizar este discurso hegemónico del pasado, como es el caso de la película También la lluvia. Al hacerlo, afectan necesariamente la visión de la sociedad presente en donde se produce ese audiovisual.

Para definir qué es el cine histórico, primero es menester considerar qué tipo de análisis se va a realizar: si sólo se va a hacer una lectura contextual, entonces podemos determinar que cualquier audiovisual tiene valor histórico, puesto que es un documento de época. Este tipo de operación es la que hace Pierre Sorlin en su famoso libro Sociología del cine (1985), donde estudia la filmografía italiana de posguerra. Si, por añadidura, se va a considerar el film como discurso histórico que interpreta los hechos que representa, entonces es necesario la determinación de lo que se considera un audiovisual propiamente histórico.

Uno de los primeros en plantear una definición concreta fue Marc Ferro. Para él existen cuatro tipos de films históricos: los que reconstruyen acontecimientos (los menos); aquellos en los que la historia no es objeto, sino que sirve de marco a una intriga (los más); las películas de la memoria, en las que el testimonio de los vivos ayuda a conservar los hechos del pasado; y ciertos films donde los cineastas, sin decir que juegan a ser historiadores, utilizan su arte para rebuscar en el pasado los hechos o situaciones que les permitan servirse de ellos. Aquí, lo más importante es la forma que adopta la inventiva, ya que la elaboración de la película permite a los cineastas «revelar cosas no dichas y mostrar el reverso de una sociedad, desempeñando tal suceso una función reveladora, un síntoma, aunque por su naturaleza no cambie el curso de la historia» (Ferro, 2008: 10). Esta definición de film histórico está en estrecha consonancia con la idea que tiene el autor sobre la función de reflejo del film con respecto a la sociedad, como algo que se puede develar mediante la observación científica, al igual que los sueños.

El otro gran referente del estudio de la relación entre cine e historia es el estadounidense Robert Rosenstone. Para él, existen dos grandes grupos de films: los tradicionales y los posmodernos. En cuanto a los primeros, pasa algo parecido que con la historia tradicional: como los cineastas están obsesionados con el realismo, asumen valores estéticos de la novela del siglo xix y muestran el pasado de una forma que no suscita interrogantes, sino que los suprimen. Claro está que dar cuenta de la historia mediante una forma dramática implica algunos cambios importantes respecto del relato escrito. La cantidad de información propiamente histórica que se puede proporcionar en dos horas es menor, aunque se puede facilitar otro tipo de datos: «al tiempo que privilegia la información visual y emocional el cine está alterando sutilmente nuestro concepto del pasado» (Rosenstone, 1997:34). Esta ficción de los films históricos dramáticos es equivalente a la historia escrita tradicional, que descansa en lo empírico como si fuese lo real. La diferencia entre uno y otro es que la vivencia del mundo visual siempre parece más verídica que la creada por el mundo escrito. Tal y como sucede con la escritura tradicional de la historia, para él estas películas no logran forjar una nueva relación con el pasado.

17 En cambio los segundos, son para Rosenstone obras que reinventan la historia, que rechazan la ilusión de que la pantalla es una ventana abierta al pasado y por lo tanto utilizan las capacidades inherentes al medio para crear múltiples significados. Estas son películas de densidad intelectual que proponen novedosos procedimientos para tratar el material histórico. La importancia de estos audiovisuales no radica en su fidelidad a los detalles sino en la manera como han decidido exponer el pasado. Son films que 
señalan el camino hacia los modos narrativos del siglo $\mathrm{xx}$, hacia las necesarias formas de la modernidad e incluso de la posmodernidad, hacia los métodos de representación dramática del significado del material histórico. No son obras que sólo muestran el pasado, sino que explican cómo y qué significa para el director en la actualidad ese pasado.

Queda claro que tanto Rosenstone como Ferro destacan aquellos films no tradicionales por sobre los que apuntan a una reconstrucción verosímil y buscan la fidelidad del relato hegemónico del pasado. Más allá de que no estamos de acuerdo del todo sobre la valoración extremadamente negativa que los autores hacen de este tipo de audiovisuales, para este caso más nos sirve la visión positiva que tienen de aquellos films novedosos, plurales, donde los cineastas encuentran nuevas formas de acercarse al pasado y plantearse cuestionamientos. Y esto es así porque También la lluvia entra claramente en esta categoría. En ella, su directora y guionista sitúan la acción en un lugar y un momento conflictivos, y el tratamiento de los hechos del pasado lejano está puesto al servicio de una representación crítica de eventos propios de un pasado muy reciente.

\section{Un discurso sobre la Conquista de América que nos habla del imperialismo del presente}

También la lluvia está construida en torno a dicotomías y paralelismos: a lo largo de toda la obra, se desarrollan ejes de conflicto, oposición y similitudes que tienen distintos niveles y alcances y confluyen en la creación de un discurso actual y crítico sobre la Conquista de América. Para analizarlos nos resulta útil traer a colación la aplicación de la teoría semiótica y el análisis narrativo del film que presenta Eugenio Sulbarán Piñeriro, y que resume en el siguiente cuadro: 


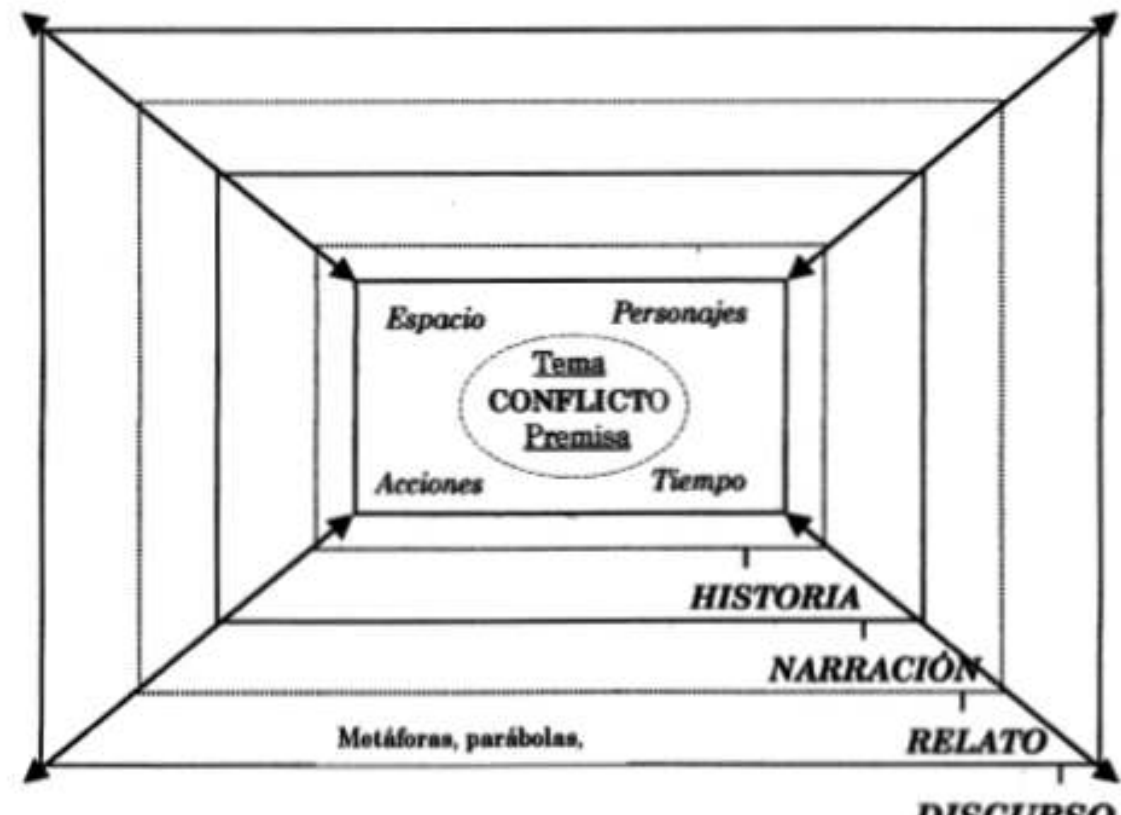

Cuadro 1. Fuente: Sulbarán Piñeiro (2000: 69)

autor explica que para analizar un audiovisual, debemos tener en cuenta en primer lugar los elementos básicos del mismo. Por ello sitúa en el centro del su gráfico al conflicto, que junto con el tema y la premisa forman el núcleo del film argumental. Alrededor se encuentra la determinación del espacio y el tiempo, donde actuarán los personajes. Todos estos componentes forman la historia, que a la vez está incluida en una forma de narrar y de relatar específicas del film. Lo interesante es que si bien el proceso de construcción del audiovisual se genera del centro hacia fuera del recuadro, el análisis del mismo debe partir desde afuera hacia adentro, o sea, desde el film como discurso, pasando por el análisis del relato y la narración, hasta comprender los elementos básicos que hacen a la historia (Sulbarán Piñeiro, 2000: 69-70).

Siguiendo este modelo, y basándonos en las definiciones que propone Jaques Aumont para los conceptos de relato, narración e historia ${ }^{8}$, podemos decir que También la lluvia nos ofrece un discurso crítico sobre la opresión de países extranjeros hacia comunidades empobrecidas y expoliadas; haciendo hincapié en la constancia de dicha situación de dominación, que se repite desde los comienzos de la conquista de América por parte de Europa hasta la actualidad (incluso por parte de aquellos que intentan poner al descubierto esta realidad). Esto se puede ver en numerosas escenas. Por ejemplo, en la apertura cuando se presentan los títulos, se muestra una enorme cruz (tan grande que recuerda a los maderos donde Jesús fue clavado) que es llevada en helicóptero hacia la selva. Luego esta misma cruz debe ser colocada en la tierra: para ahorrar dinero en grúas y especialistas, Costa encarga la tarea a los quechuas contratados para la escenografía, sin entregarles herramientas ni protección y poniéndolos en abierto peligro; lo cual se asemeja mucho al maltrato que le otorgaban los conquistadores a los indígenas de toda América entre los siglos XV y XVIII. Así, en una corta escena, Bollaín y su equipo nos tienden una línea crítica de la actitud de los españoles hacia los latinoamericanos, desde la conquista hasta la actualidad. 

tomas impactantes en el medio de la selva, una enorme cantidad de extras y diálogos comprometidos con la historia que se relata. Siguiendo a Aumont y a su concepto dual de instancia narrativa ${ }^{9}$; encontramos una instancia narrativa ficticia asumida por varios personajes, entre los cuales se destaca el de María (la asistente de producción, interpretada por Cassandra Ciangherotti) quien gracias a su intención de hacer un documental acompaña la filmación de la película de Sebastián, entrevista al director y a los actores y también se involucra en la documentación de los hechos concernientes al presente de la película, o sea la Guerra del Agua. Su presencia es bastante constante y une las distintas temáticas tratadas en la obra; y por eso asume la instancia narrativa interna en varias ocasiones.

Como el mismo Aumont lo destaca, la instancia narrativa real es mucho más difícil de descubrir, puesto que no podemos dar cuenta de todas las decisiones que tomó el equipo que elaboró También la lluvia. Sí podemos destacar algunos elementos que se dejan traslucir en la propia obra. El más interesante para nuestro campo de estudio, creemos, es la forma en que se construye la narración en relación al tratamiento de eventos pasados lejanos y recientes. Para representar la llegada de Colón a América, Bollaín y su equipo deciden escenificar el proceso de realización de una película grandilocuente y tradicional, al estilo clásico de Hollywood, donde se busca una fuerte verosimilitud en la recreación de los hechos y se montan las escenas de manera que no se note la hechura del film (entre otros elementos que hacen al cine clásico) ${ }^{10}$. Lo interesante del complejo audiovisual que aquí se estudia, es que en el devenir de su historia se cuenta el proceso de hacer una película, y en ese caso, podemos ver la representación de la instancia narrativa real (del film de Sebastián, no del de Bollaín), donde el personaje del cineasta y el del productor, toman las decisiones para producir un relato fílmico, en este caso, una obra sobre la llegada de Colón a América.

Mientras, el largometraje propiamente dicho pone en duda este estilo clásico realista permitiendo la construcción de una narración compleja, con distintos niveles, que da pie al debate, la crítica y la reflexión. Esto se puede ver en el personaje que hace de Colón, quien constantemente está cuestionando el guión tan cercano a la verosimilitud extrema que le presenta el director Sebastián. Por ejemplo, cuando debe recitar palabra por palabra la carta que el comisionado le envió a los Reyes Católicos describiéndole las nuevas tierras encontradas. Para Antón (quien interpreta a Colón en el film de Sebastián) esto es demasiado acartonado, poco espontáneo, y no deja ver ni la sensibilidad ni las tribulaciones de su personaje. En su figura, Antón encarna el cuestionamiento a una forma de filmar, apegada a una supuesta fidelidad hacia lo que sucedió; y también de alguna manera extiende esta crítica a la manera tradicional en la que Cristóbal Colón fue representado en la filmografía española. Al respecto Rafael de España explica que:

Las aproximaciones cinematográficas al personaje clave de la Historia de América se acogen a los mismos criterios de sus biografías escritas, es decir, oscilan entre la extasiada alabanza y la crítica más o menos agresiva. La primera opción ha sido la más habitual, pues al fin y al cabo es la que más se ajusta a las pautas del film biográfico tradicional. (1992: 190)

La narración de Bollaín, al estar construida al estilo de lo que Rosenstone llama film posmoderno, permite correrse de las típicas actitudes de alabanza o crítica para plantear directamente un problema, es decir, para poner en cuestionamiento la forma de representación verosímil de un personaje tan importante del pasado. 

Bollaín y su equipo interpretan eventos del pasado (tanto lejanos como recientes); y
es el estudio de los personajes, sus diálogos y acciones una de las formas de poner
al descubierto lo que directora y guionista tienen para decir sobre aquello que
representan. Sirva de ejemplo la descripción y el análisis del diálogo de la siguiente
escena. Camino a la selva, donde van a hacer algunas tomas para la película, la asistente
de producción le pregunta a Sebastián sobre su lugar de filmación, puesto que parece
no tener sentido: están en Bolivia, a 2500 metros sobre el nivel del mar, entre las
montañas y a miles de quilómetros del Caribe (lugar de la llegada de Colón y ambiente
lógico de la historia que quieren contar). El responsable de esa situación es Costa, quien
explica que «esto está lleno de indígenas hambrientos y eso significa extras, miles de
extras. Nada de recurrir a esa mierda de efectos digitales, quiero poderío, que se vea
que nos hemos gastado la pasta». Sebastián le dice que esto podría ser un gran
problema, porque los rasgos de sus actores quechuas son muy distintos a los indios
taínos del guión de su película: ¿qué hace Colón entrevistándose con indígenas de los
Andes? Pero para Costa, son indígenas, sean de donde sean ya que «son todos iguales».
Si Sebastián hubiese aceptado inversores estadounidenses, otro sería el presupuesto y
el lugar de filmación, pero ya que no lo hizo, deberán conformarse con Bolivia. Para
Sebastián hacer una obra donde los españoles hablasen en inglés era una aberración
porque «los españoles hablan en español». La respuesta de su asistente de producción
deja al descubierto lo superficial de su postura: «Entonces, ¿los españoles hablan en
español, pero los taínos que encontró Colón hablan quechua?». En esta escena, la
presencia de la asistente de dirección y sus preguntas inquisitivas están destinadas a
establecer un elemento importante con respecto a la recreación de hechos pasados: Bollaín y su equipo interpretan eventos del pasado (tanto lejanos como recientes); y
es el estudio de los personajes, sus diálogos y acciones una de las formas de poner
al descubierto lo que directora y guionista tienen para decir sobre aquello que
representan. Sirva de ejemplo la descripción y el análisis del diálogo de la siguiente
escena. Camino a la selva, donde van a hacer algunas tomas para la película, la asistente
de producción le pregunta a Sebastián sobre su lugar de filmación, puesto que parece
no tener sentido: están en Bolivia, a 2500 metros sobre el nivel del mar, entre las
montañas y a miles de quilómetros del Caribe (lugar de la llegada de Colón y ambiente
lógico de la historia que quieren contar). El responsable de esa situación es Costa, quien
explica que «esto está lleno de indígenas hambrientos y eso significa extras, miles de
extras. Nada de recurrir a esa mierda de efectos digitales, quiero poderío, que se vea
que nos hemos gastado la pasta». Sebastián le dice que esto podría ser un gran
problema, porque los rasgos de sus actores quechuas son muy distintos a los indios
taínos del guión de su película: ¿qué hace Colón entrevistándose con indígenas de los
Andes? Pero para Costa, son indígenas, sean de donde sean ya que «son todos iguales».
Si Sebastián hubiese aceptado inversores estadounidenses, otro sería el presupuesto y
el lugar de filmación, pero ya que no lo hizo, deberán conformarse con Bolivia. Para
Sebastián hacer una obra donde los españoles hablasen en inglés era una aberración
porque «los españoles hablan en español». La respuesta de su asistente de producción
deja al descubierto lo superficial de su postura: «Entonces, ¿los españoles hablan en
español, pero los taínos que encontró Colón hablan quechua?». En esta escena, la
presencia de la asistente de dirección y sus preguntas inquisitivas están destinadas a
establecer un elemento importante con respecto a la recreación de hechos pasados: Bollaín y su equipo interpretan eventos del pasado (tanto lejanos como recientes); y
es el estudio de los personajes, sus diálogos y acciones una de las formas de poner
al descubierto lo que directora y guionista tienen para decir sobre aquello que
representan. Sirva de ejemplo la descripción y el análisis del diálogo de la siguiente
escena. Camino a la selva, donde van a hacer algunas tomas para la película, la asistente
de producción le pregunta a Sebastián sobre su lugar de filmación, puesto que parece
no tener sentido: están en Bolivia, a 2500 metros sobre el nivel del mar, entre las
montañas y a miles de quilómetros del Caribe (lugar de la llegada de Colón y ambiente
lógico de la historia que quieren contar). El responsable de esa situación es Costa, quien
explica que «esto está lleno de indígenas hambrientos y eso significa extras, miles de
extras. Nada de recurrir a esa mierda de efectos digitales, quiero poderío, que se vea
que nos hemos gastado la pasta». Sebastián le dice que esto podría ser un gran
problema, porque los rasgos de sus actores quechuas son muy distintos a los indios
taínos del guión de su película: ¿qué hace Colón entrevistándose con indígenas de los
Andes? Pero para Costa, son indígenas, sean de donde sean ya que «son todos iguales».
Si Sebastián hubiese aceptado inversores estadounidenses, otro sería el presupuesto y
el lugar de filmación, pero ya que no lo hizo, deberán conformarse con Bolivia. Para
Sebastián hacer una obra donde los españoles hablasen en inglés era una aberración
porque «los españoles hablan en español». La respuesta de su asistente de producción
deja al descubierto lo superficial de su postura: «Entonces, ¿los españoles hablan en
español, pero los taínos que encontró Colón hablan quechua?». En esta escena, la
presencia de la asistente de dirección y sus preguntas inquisitivas están destinadas a
establecer un elemento importante con respecto a la recreación de hechos pasados: Bollaín y su equipo interpretan eventos del pasado (tanto lejanos como recientes); y
es el estudio de los personajes, sus diálogos y acciones una de las formas de poner
al descubierto lo que directora y guionista tienen para decir sobre aquello que
representan. Sirva de ejemplo la descripción y el análisis del diálogo de la siguiente
escena. Camino a la selva, donde van a hacer algunas tomas para la película, la asistente
de producción le pregunta a Sebastián sobre su lugar de filmación, puesto que parece
no tener sentido: están en Bolivia, a 2500 metros sobre el nivel del mar, entre las
montañas y a miles de quilómetros del Caribe (lugar de la llegada de Colón y ambiente
lógico de la historia que quieren contar). El responsable de esa situación es Costa, quien
explica que «esto está lleno de indígenas hambrientos y eso significa extras, miles de
extras. Nada de recurrir a esa mierda de efectos digitales, quiero poderío, que se vea
que nos hemos gastado la pasta». Sebastián le dice que esto podría ser un gran
problema, porque los rasgos de sus actores quechuas son muy distintos a los indios
taínos del guión de su película: ¿qué hace Colón entrevistándose con indígenas de los
Andes? Pero para Costa, son indígenas, sean de donde sean ya que «son todos iguales».
Si Sebastián hubiese aceptado inversores estadounidenses, otro sería el presupuesto y
el lugar de filmación, pero ya que no lo hizo, deberán conformarse con Bolivia. Para
Sebastián hacer una obra donde los españoles hablasen en inglés era una aberración
porque «los españoles hablan en español». La respuesta de su asistente de producción
deja al descubierto lo superficial de su postura: «Entonces, ¿los españoles hablan en
español, pero los taínos que encontró Colón hablan quechua?». En esta escena, la
presencia de la asistente de dirección y sus preguntas inquisitivas están destinadas a
establecer un elemento importante con respecto a la recreación de hechos pasados: Bollaín y su equipo interpretan eventos del pasado (tanto lejanos como recientes); y
es el estudio de los personajes, sus diálogos y acciones una de las formas de poner
al descubierto lo que directora y guionista tienen para decir sobre aquello que
representan. Sirva de ejemplo la descripción y el análisis del diálogo de la siguiente
escena. Camino a la selva, donde van a hacer algunas tomas para la película, la asistente
de producción le pregunta a Sebastián sobre su lugar de filmación, puesto que parece
no tener sentido: están en Bolivia, a 2500 metros sobre el nivel del mar, entre las
montañas y a miles de quilómetros del Caribe (lugar de la llegada de Colón y ambiente
lógico de la historia que quieren contar). El responsable de esa situación es Costa, quien
explica que «esto está lleno de indígenas hambrientos y eso significa extras, miles de
extras. Nada de recurrir a esa mierda de efectos digitales, quiero poderío, que se vea
que nos hemos gastado la pasta». Sebastián le dice que esto podría ser un gran
problema, porque los rasgos de sus actores quechuas son muy distintos a los indios
taínos del guión de su película: ¿qué hace Colón entrevistándose con indígenas de los
Andes? Pero para Costa, son indígenas, sean de donde sean ya que «son todos iguales».
Si Sebastián hubiese aceptado inversores estadounidenses, otro sería el presupuesto y
el lugar de filmación, pero ya que no lo hizo, deberán conformarse con Bolivia. Para
Sebastián hacer una obra donde los españoles hablasen en inglés era una aberración
porque «los españoles hablan en español». La respuesta de su asistente de producción
deja al descubierto lo superficial de su postura: «Entonces, ¿los españoles hablan en
español, pero los taínos que encontró Colón hablan quechua?». En esta escena, la
presencia de la asistente de dirección y sus preguntas inquisitivas están destinadas a
establecer un elemento importante con respecto a la recreación de hechos pasados: Bollaín y su equipo interpretan eventos del pasado (tanto lejanos como recientes); y
es el estudio de los personajes, sus diálogos y acciones una de las formas de poner
al descubierto lo que directora y guionista tienen para decir sobre aquello que
representan. Sirva de ejemplo la descripción y el análisis del diálogo de la siguiente
escena. Camino a la selva, donde van a hacer algunas tomas para la película, la asistente
de producción le pregunta a Sebastián sobre su lugar de filmación, puesto que parece
no tener sentido: están en Bolivia, a 2500 metros sobre el nivel del mar, entre las
montañas y a miles de quilómetros del Caribe (lugar de la llegada de Colón y ambiente
lógico de la historia que quieren contar). El responsable de esa situación es Costa, quien
explica que «esto está lleno de indígenas hambrientos y eso significa extras, miles de
extras. Nada de recurrir a esa mierda de efectos digitales, quiero poderío, que se vea
que nos hemos gastado la pasta». Sebastián le dice que esto podría ser un gran
problema, porque los rasgos de sus actores quechuas son muy distintos a los indios
taínos del guión de su película: ¿qué hace Colón entrevistándose con indígenas de los
Andes? Pero para Costa, son indígenas, sean de donde sean ya que «son todos iguales».
Si Sebastián hubiese aceptado inversores estadounidenses, otro sería el presupuesto y
el lugar de filmación, pero ya que no lo hizo, deberán conformarse con Bolivia. Para
Sebastián hacer una obra donde los españoles hablasen en inglés era una aberración
porque «los españoles hablan en español». La respuesta de su asistente de producción
deja al descubierto lo superficial de su postura: «Entonces, ¿los españoles hablan en
español, pero los taínos que encontró Colón hablan quechua?». En esta escena, la
presencia de la asistente de dirección y sus preguntas inquisitivas están destinadas a
establecer un elemento importante con respecto a la recreación de hechos pasados: Bollaín y su equipo interpretan eventos del pasado (tanto lejanos como recientes); y
es el estudio de los personajes, sus diálogos y acciones una de las formas de poner
al descubierto lo que directora y guionista tienen para decir sobre aquello que
representan. Sirva de ejemplo la descripción y el análisis del diálogo de la siguiente
escena. Camino a la selva, donde van a hacer algunas tomas para la película, la asistente
de producción le pregunta a Sebastián sobre su lugar de filmación, puesto que parece
no tener sentido: están en Bolivia, a 2500 metros sobre el nivel del mar, entre las
montañas y a miles de quilómetros del Caribe (lugar de la llegada de Colón y ambiente
lógico de la historia que quieren contar). El responsable de esa situación es Costa, quien
explica que «esto está lleno de indígenas hambrientos y eso significa extras, miles de
extras. Nada de recurrir a esa mierda de efectos digitales, quiero poderío, que se vea
que nos hemos gastado la pasta». Sebastián le dice que esto podría ser un gran
problema, porque los rasgos de sus actores quechuas son muy distintos a los indios
taínos del guión de su película: ¿qué hace Colón entrevistándose con indígenas de los
Andes? Pero para Costa, son indígenas, sean de donde sean ya que «son todos iguales».
Si Sebastián hubiese aceptado inversores estadounidenses, otro sería el presupuesto y
el lugar de filmación, pero ya que no lo hizo, deberán conformarse con Bolivia. Para
Sebastián hacer una obra donde los españoles hablasen en inglés era una aberración
porque «los españoles hablan en español». La respuesta de su asistente de producción
deja al descubierto lo superficial de su postura: «Entonces, ¿los españoles hablan en
español, pero los taínos que encontró Colón hablan quechua?». En esta escena, la
presencia de la asistente de dirección y sus preguntas inquisitivas están destinadas a
establecer un elemento importante con respecto a la recreación de hechos pasados: Bollaín y su equipo interpretan eventos del pasado (tanto lejanos como recientes); y
es el estudio de los personajes, sus diálogos y acciones una de las formas de poner
al descubierto lo que directora y guionista tienen para decir sobre aquello que
representan. Sirva de ejemplo la descripción y el análisis del diálogo de la siguiente
escena. Camino a la selva, donde van a hacer algunas tomas para la película, la asistente
de producción le pregunta a Sebastián sobre su lugar de filmación, puesto que parece
no tener sentido: están en Bolivia, a 2500 metros sobre el nivel del mar, entre las
montañas y a miles de quilómetros del Caribe (lugar de la llegada de Colón y ambiente
lógico de la historia que quieren contar). El responsable de esa situación es Costa, quien
explica que «esto está lleno de indígenas hambrientos y eso significa extras, miles de
extras. Nada de recurrir a esa mierda de efectos digitales, quiero poderío, que se vea
que nos hemos gastado la pasta». Sebastián le dice que esto podría ser un gran
problema, porque los rasgos de sus actores quechuas son muy distintos a los indios
taínos del guión de su película: ¿qué hace Colón entrevistándose con indígenas de los
Andes? Pero para Costa, son indígenas, sean de donde sean ya que «son todos iguales».
Si Sebastián hubiese aceptado inversores estadounidenses, otro sería el presupuesto y
el lugar de filmación, pero ya que no lo hizo, deberán conformarse con Bolivia. Para
Sebastián hacer una obra donde los españoles hablasen en inglés era una aberración
porque «los españoles hablan en español». La respuesta de su asistente de producción
deja al descubierto lo superficial de su postura: «Entonces, ¿los españoles hablan en
español, pero los taínos que encontró Colón hablan quechua?». En esta escena, la
presencia de la asistente de dirección y sus preguntas inquisitivas están destinadas a
establecer un elemento importante con respecto a la recreación de hechos pasados: Bollaín y su equipo interpretan eventos del pasado (tanto lejanos como recientes); y
es el estudio de los personajes, sus diálogos y acciones una de las formas de poner
al descubierto lo que directora y guionista tienen para decir sobre aquello que
representan. Sirva de ejemplo la descripción y el análisis del diálogo de la siguiente
escena. Camino a la selva, donde van a hacer algunas tomas para la película, la asistente
de producción le pregunta a Sebastián sobre su lugar de filmación, puesto que parece
no tener sentido: están en Bolivia, a 2500 metros sobre el nivel del mar, entre las
montañas y a miles de quilómetros del Caribe (lugar de la llegada de Colón y ambiente
lógico de la historia que quieren contar). El responsable de esa situación es Costa, quien
explica que «esto está lleno de indígenas hambrientos y eso significa extras, miles de
extras. Nada de recurrir a esa mierda de efectos digitales, quiero poderío, que se vea
que nos hemos gastado la pasta». Sebastián le dice que esto podría ser un gran
problema, porque los rasgos de sus actores quechuas son muy distintos a los indios
taínos del guión de su película: ¿qué hace Colón entrevistándose con indígenas de los
Andes? Pero para Costa, son indígenas, sean de donde sean ya que «son todos iguales».
Si Sebastián hubiese aceptado inversores estadounidenses, otro sería el presupuesto y
el lugar de filmación, pero ya que no lo hizo, deberán conformarse con Bolivia. Para
Sebastián hacer una obra donde los españoles hablasen en inglés era una aberración
porque «los españoles hablan en español». La respuesta de su asistente de producción
deja al descubierto lo superficial de su postura: «Entonces, ¿los españoles hablan en
español, pero los taínos que encontró Colón hablan quechua?». En esta escena, la
presencia de la asistente de dirección y sus preguntas inquisitivas están destinadas a
establecer un elemento importante con respecto a la recreación de hechos pasados: Bollaín y su equipo interpretan eventos del pasado (tanto lejanos como recientes); y
es el estudio de los personajes, sus diálogos y acciones una de las formas de poner
al descubierto lo que directora y guionista tienen para decir sobre aquello que
representan. Sirva de ejemplo la descripción y el análisis del diálogo de la siguiente
escena. Camino a la selva, donde van a hacer algunas tomas para la película, la asistente
de producción le pregunta a Sebastián sobre su lugar de filmación, puesto que parece
no tener sentido: están en Bolivia, a 2500 metros sobre el nivel del mar, entre las
montañas y a miles de quilómetros del Caribe (lugar de la llegada de Colón y ambiente
lógico de la historia que quieren contar). El responsable de esa situación es Costa, quien
explica que «esto está lleno de indígenas hambrientos y eso significa extras, miles de
extras. Nada de recurrir a esa mierda de efectos digitales, quiero poderío, que se vea
que nos hemos gastado la pasta». Sebastián le dice que esto podría ser un gran
problema, porque los rasgos de sus actores quechuas son muy distintos a los indios
taínos del guión de su película: ¿qué hace Colón entrevistándose con indígenas de los
Andes? Pero para Costa, son indígenas, sean de donde sean ya que «son todos iguales».
Si Sebastián hubiese aceptado inversores estadounidenses, otro sería el presupuesto y
el lugar de filmación, pero ya que no lo hizo, deberán conformarse con Bolivia. Para
Sebastián hacer una obra donde los españoles hablasen en inglés era una aberración
porque «los españoles hablan en español». La respuesta de su asistente de producción
deja al descubierto lo superficial de su postura: «Entonces, ¿los españoles hablan en
español, pero los taínos que encontró Colón hablan quechua?». En esta escena, la
presencia de la asistente de dirección y sus preguntas inquisitivas están destinadas a
establecer un elemento importante con respecto a la recreación de hechos pasados: Bollaín y su equipo interpretan eventos del pasado (tanto lejanos como recientes); y
es el estudio de los personajes, sus diálogos y acciones una de las formas de poner
al descubierto lo que directora y guionista tienen para decir sobre aquello que
representan. Sirva de ejemplo la descripción y el análisis del diálogo de la siguiente
escena. Camino a la selva, donde van a hacer algunas tomas para la película, la asistente
de producción le pregunta a Sebastián sobre su lugar de filmación, puesto que parece
no tener sentido: están en Bolivia, a 2500 metros sobre el nivel del mar, entre las
montañas y a miles de quilómetros del Caribe (lugar de la llegada de Colón y ambiente
lógico de la historia que quieren contar). El responsable de esa situación es Costa, quien
explica que «esto está lleno de indígenas hambrientos y eso significa extras, miles de
extras. Nada de recurrir a esa mierda de efectos digitales, quiero poderío, que se vea
que nos hemos gastado la pasta». Sebastián le dice que esto podría ser un gran
problema, porque los rasgos de sus actores quechuas son muy distintos a los indios
taínos del guión de su película: ¿qué hace Colón entrevistándose con indígenas de los
Andes? Pero para Costa, son indígenas, sean de donde sean ya que «son todos iguales».
Si Sebastián hubiese aceptado inversores estadounidenses, otro sería el presupuesto y
el lugar de filmación, pero ya que no lo hizo, deberán conformarse con Bolivia. Para
Sebastián hacer una obra donde los españoles hablasen en inglés era una aberración
porque «los españoles hablan en español». La respuesta de su asistente de producción
deja al descubierto lo superficial de su postura: «Entonces, ¿los españoles hablan en
español, pero los taínos que encontró Colón hablan quechua?». En esta escena, la
presencia de la asistente de dirección y sus preguntas inquisitivas están destinadas a
establecer un elemento importante con respecto a la recreación de hechos pasados: Bollaín y su equipo interpretan eventos del pasado (tanto lejanos como recientes); y
es el estudio de los personajes, sus diálogos y acciones una de las formas de poner
al descubierto lo que directora y guionista tienen para decir sobre aquello que
representan. Sirva de ejemplo la descripción y el análisis del diálogo de la siguiente
escena. Camino a la selva, donde van a hacer algunas tomas para la película, la asistente
de producción le pregunta a Sebastián sobre su lugar de filmación, puesto que parece
no tener sentido: están en Bolivia, a 2500 metros sobre el nivel del mar, entre las
montañas y a miles de quilómetros del Caribe (lugar de la llegada de Colón y ambiente
lógico de la historia que quieren contar). El responsable de esa situación es Costa, quien
explica que «esto está lleno de indígenas hambrientos y eso significa extras, miles de
extras. Nada de recurrir a esa mierda de efectos digitales, quiero poderío, que se vea
que nos hemos gastado la pasta». Sebastián le dice que esto podría ser un gran
problema, porque los rasgos de sus actores quechuas son muy distintos a los indios
taínos del guión de su película: ¿qué hace Colón entrevistándose con indígenas de los
Andes? Pero para Costa, son indígenas, sean de donde sean ya que «son todos iguales».
Si Sebastián hubiese aceptado inversores estadounidenses, otro sería el presupuesto y
el lugar de filmación, pero ya que no lo hizo, deberán conformarse con Bolivia. Para
Sebastián hacer una obra donde los españoles hablasen en inglés era una aberración
porque «los españoles hablan en español». La respuesta de su asistente de producción
deja al descubierto lo superficial de su postura: «Entonces, ¿los españoles hablan en
español, pero los taínos que encontró Colón hablan quechua?». En esta escena, la
presencia de la asistente de dirección y sus preguntas inquisitivas están destinadas a
establecer un elemento importante con respecto a la recreación de hechos pasados: Bollaín y su equipo interpretan eventos del pasado (tanto lejanos como recientes); y
es el estudio de los personajes, sus diálogos y acciones una de las formas de poner
al descubierto lo que directora y guionista tienen para decir sobre aquello que
representan. Sirva de ejemplo la descripción y el análisis del diálogo de la siguiente
escena. Camino a la selva, donde van a hacer algunas tomas para la película, la asistente
de producción le pregunta a Sebastián sobre su lugar de filmación, puesto que parece
no tener sentido: están en Bolivia, a 2500 metros sobre el nivel del mar, entre las
montañas y a miles de quilómetros del Caribe (lugar de la llegada de Colón y ambiente
lógico de la historia que quieren contar). El responsable de esa situación es Costa, quien
explica que «esto está lleno de indígenas hambrientos y eso significa extras, miles de
extras. Nada de recurrir a esa mierda de efectos digitales, quiero poderío, que se vea
que nos hemos gastado la pasta». Sebastián le dice que esto podría ser un gran
problema, porque los rasgos de sus actores quechuas son muy distintos a los indios
taínos del guión de su película: ¿qué hace Colón entrevistándose con indígenas de los
Andes? Pero para Costa, son indígenas, sean de donde sean ya que «son todos iguales».
Si Sebastián hubiese aceptado inversores estadounidenses, otro sería el presupuesto y
el lugar de filmación, pero ya que no lo hizo, deberán conformarse con Bolivia. Para
Sebastián hacer una obra donde los españoles hablasen en inglés era una aberración
porque «los españoles hablan en español». La respuesta de su asistente de producción
deja al descubierto lo superficial de su postura: «Entonces, ¿los españoles hablan en
español, pero los taínos que encontró Colón hablan quechua?». En esta escena, la
presencia de la asistente de dirección y sus preguntas inquisitivas están destinadas a
establecer un elemento importante con respecto a la recreación de hechos pasados: Bollaín y su equipo interpretan eventos del pasado (tanto lejanos como recientes); y
es el estudio de los personajes, sus diálogos y acciones una de las formas de poner
al descubierto lo que directora y guionista tienen para decir sobre aquello que
representan. Sirva de ejemplo la descripción y el análisis del diálogo de la siguiente
escena. Camino a la selva, donde van a hacer algunas tomas para la película, la asistente
de producción le pregunta a Sebastián sobre su lugar de filmación, puesto que parece
no tener sentido: están en Bolivia, a 2500 metros sobre el nivel del mar, entre las
montañas y a miles de quilómetros del Caribe (lugar de la llegada de Colón y ambiente
lógico de la historia que quieren contar). El responsable de esa situación es Costa, quien
explica que «esto está lleno de indígenas hambrientos y eso significa extras, miles de
extras. Nada de recurrir a esa mierda de efectos digitales, quiero poderío, que se vea
que nos hemos gastado la pasta». Sebastián le dice que esto podría ser un gran
problema, porque los rasgos de sus actores quechuas son muy distintos a los indios
taínos del guión de su película: ¿qué hace Colón entrevistándose con indígenas de los
Andes? Pero para Costa, son indígenas, sean de donde sean ya que «son todos iguales».
Si Sebastián hubiese aceptado inversores estadounidenses, otro sería el presupuesto y
el lugar de filmación, pero ya que no lo hizo, deberán conformarse con Bolivia. Para
Sebastián hacer una obra donde los españoles hablasen en inglés era una aberración
porque «los españoles hablan en español». La respuesta de su asistente de producción
deja al descubierto lo superficial de su postura: «Entonces, ¿los españoles hablan en
español, pero los taínos que encontró Colón hablan quechua?». En esta escena, la
presencia de la asistente de dirección y sus preguntas inquisitivas están destinadas a
establecer un elemento importante con respecto a la recreación de hechos pasados: Bollaín y su equipo interpretan eventos del pasado (tanto lejanos como recientes); y
es el estudio de los personajes, sus diálogos y acciones una de las formas de poner
al descubierto lo que directora y guionista tienen para decir sobre aquello que
representan. Sirva de ejemplo la descripción y el análisis del diálogo de la siguiente
escena. Camino a la selva, donde van a hacer algunas tomas para la película, la asistente
de producción le pregunta a Sebastián sobre su lugar de filmación, puesto que parece
no tener sentido: están en Bolivia, a 2500 metros sobre el nivel del mar, entre las
montañas y a miles de quilómetros del Caribe (lugar de la llegada de Colón y ambiente
lógico de la historia que quieren contar). El responsable de esa situación es Costa, quien
explica que «esto está lleno de indígenas hambrientos y eso significa extras, miles de
extras. Nada de recurrir a esa mierda de efectos digitales, quiero poderío, que se vea
que nos hemos gastado la pasta». Sebastián le dice que esto podría ser un gran
problema, porque los rasgos de sus actores quechuas son muy distintos a los indios
taínos del guión de su película: ¿qué hace Colón entrevistándose con indígenas de los
Andes? Pero para Costa, son indígenas, sean de donde sean ya que «son todos iguales».
Si Sebastián hubiese aceptado inversores estadounidenses, otro sería el presupuesto y
el lugar de filmación, pero ya que no lo hizo, deberán conformarse con Bolivia. Para
Sebastián hacer una obra donde los españoles hablasen en inglés era una aberración
porque «los españoles hablan en español». La respuesta de su asistente de producción
deja al descubierto lo superficial de su postura: «Entonces, ¿los españoles hablan en
español, pero los taínos que encontró Colón hablan quechua?». En esta escena, la
presencia de la asistente de dirección y sus preguntas inquisitivas están destinadas a
establecer un elemento importante con respecto a la recreación de hechos pasados: Bollaín y su equipo interpretan eventos del pasado (tanto lejanos como recientes); y
es el estudio de los personajes, sus diálogos y acciones una de las formas de poner
al descubierto lo que directora y guionista tienen para decir sobre aquello que
representan. Sirva de ejemplo la descripción y el análisis del diálogo de la siguiente
escena. Camino a la selva, donde van a hacer algunas tomas para la película, la asistente
de producción le pregunta a Sebastián sobre su lugar de filmación, puesto que parece
no tener sentido: están en Bolivia, a 2500 metros sobre el nivel del mar, entre las
montañas y a miles de quilómetros del Caribe (lugar de la llegada de Colón y ambiente
lógico de la historia que quieren contar). El responsable de esa situación es Costa, quien
explica que «esto está lleno de indígenas hambrientos y eso significa extras, miles de
extras. Nada de recurrir a esa mierda de efectos digitales, quiero poderío, que se vea
que nos hemos gastado la pasta». Sebastián le dice que esto podría ser un gran
problema, porque los rasgos de sus actores quechuas son muy distintos a los indios
taínos del guión de su película: ¿qué hace Colón entrevistándose con indígenas de los
Andes? Pero para Costa, son indígenas, sean de donde sean ya que «son todos iguales».
Si Sebastián hubiese aceptado inversores estadounidenses, otro sería el presupuesto y
el lugar de filmación, pero ya que no lo hizo, deberán conformarse con Bolivia. Para
Sebastián hacer una obra donde los españoles hablasen en inglés era una aberración
porque «los españoles hablan en español». La respuesta de su asistente de producción
deja al descubierto lo superficial de su postura: «Entonces, ¿los españoles hablan en
español, pero los taínos que encontró Colón hablan quechua?». En esta escena, la
presencia de la asistente de dirección y sus preguntas inquisitivas están destinadas a
establecer un elemento importante con respecto a la recreación de hechos pasados: Bollaín y su equipo interpretan eventos del pasado (tanto lejanos como recientes); y
es el estudio de los personajes, sus diálogos y acciones una de las formas de poner
al descubierto lo que directora y guionista tienen para decir sobre aquello que
representan. Sirva de ejemplo la descripción y el análisis del diálogo de la siguiente
escena. Camino a la selva, donde van a hacer algunas tomas para la película, la asistente
de producción le pregunta a Sebastián sobre su lugar de filmación, puesto que parece
no tener sentido: están en Bolivia, a 2500 metros sobre el nivel del mar, entre las
montañas y a miles de quilómetros del Caribe (lugar de la llegada de Colón y ambiente
lógico de la historia que quieren contar). El responsable de esa situación es Costa, quien
explica que «esto está lleno de indígenas hambrientos y eso significa extras, miles de
extras. Nada de recurrir a esa mierda de efectos digitales, quiero poderío, que se vea
que nos hemos gastado la pasta». Sebastián le dice que esto podría ser un gran
problema, porque los rasgos de sus actores quechuas son muy distintos a los indios
taínos del guión de su película: ¿qué hace Colón entrevistándose con indígenas de los
Andes? Pero para Costa, son indígenas, sean de donde sean ya que «son todos iguales».
Si Sebastián hubiese aceptado inversores estadounidenses, otro sería el presupuesto y
el lugar de filmación, pero ya que no lo hizo, deberán conformarse con Bolivia. Para
Sebastián hacer una obra donde los españoles hablasen en inglés era una aberración
porque «los españoles hablan en español». La respuesta de su asistente de producción
deja al descubierto lo superficial de su postura: «Entonces, ¿los españoles hablan en
español, pero los taínos que encontró Colón hablan quechua?». En esta escena, la
presencia de la asistente de dirección y sus preguntas inquisitivas están destinadas a
establecer un elemento importante con respecto a la recreación de hechos pasados: Bollaín y su equipo interpretan eventos del pasado (tanto lejanos como recientes); y
es el estudio de los personajes, sus diálogos y acciones una de las formas de poner
al descubierto lo que directora y guionista tienen para decir sobre aquello que
representan. Sirva de ejemplo la descripción y el análisis del diálogo de la siguiente
escena. Camino a la selva, donde van a hacer algunas tomas para la película, la asistente
de producción le pregunta a Sebastián sobre su lugar de filmación, puesto que parece
no tener sentido: están en Bolivia, a 2500 metros sobre el nivel del mar, entre las
montañas y a miles de quilómetros del Caribe (lugar de la llegada de Colón y ambiente
lógico de la historia que quieren contar). El responsable de esa situación es Costa, quien
explica que «esto está lleno de indígenas hambrientos y eso significa extras, miles de
extras. Nada de recurrir a esa mierda de efectos digitales, quiero poderío, que se vea
que nos hemos gastado la pasta». Sebastián le dice que esto podría ser un gran
problema, porque los rasgos de sus actores quechuas son muy distintos a los indios
taínos del guión de su película: ¿qué hace Colón entrevistándose con indígenas de los
Andes? Pero para Costa, son indígenas, sean de donde sean ya que «son todos iguales».
Si Sebastián hubiese aceptado inversores estadounidenses, otro sería el presupuesto y
el lugar de filmación, pero ya que no lo hizo, deberán conformarse con Bolivia. Para
Sebastián hacer una obra donde los españoles hablasen en inglés era una aberración
porque «los españoles hablan en español». La respuesta de su asistente de producción
deja al descubierto lo superficial de su postura: «Entonces, ¿los españoles hablan en
español, pero los taínos que encontró Colón hablan quechua?». En esta escena, la
presencia de la asistente de dirección y sus preguntas inquisitivas están destinadas a
establecer un elemento importante con respecto a la recreación de hechos pasados: Bollaín y su equipo interpretan eventos del pasado (tanto lejanos como recientes); y
es el estudio de los personajes, sus diálogos y acciones una de las formas de poner
al descubierto lo que directora y guionista tienen para decir sobre aquello que
representan. Sirva de ejemplo la descripción y el análisis del diálogo de la siguiente
escena. Camino a la selva, donde van a hacer algunas tomas para la película, la asistente
de producción le pregunta a Sebastián sobre su lugar de filmación, puesto que parece
no tener sentido: están en Bolivia, a 2500 metros sobre el nivel del mar, entre las
montañas y a miles de quilómetros del Caribe (lugar de la llegada de Colón y ambiente
lógico de la historia que quieren contar). El responsable de esa situación es Costa, quien
explica que «esto está lleno de indígenas hambrientos y eso significa extras, miles de
extras. Nada de recurrir a esa mierda de efectos digitales, quiero poderío, que se vea
que nos hemos gastado la pasta». Sebastián le dice que esto podría ser un gran
problema, porque los rasgos de sus actores quechuas son muy distintos a los indios
taínos del guión de su película: ¿qué hace Colón entrevistándose con indígenas de los
Andes? Pero para Costa, son indígenas, sean de donde sean ya que «son todos iguales».
Si Sebastián hubiese aceptado inversores estadounidenses, otro sería el presupuesto y
el lugar de filmación, pero ya que no lo hizo, deberán conformarse con Bolivia. Para
Sebastián hacer una obra donde los españoles hablasen en inglés era una aberración
porque «los españoles hablan en español». La respuesta de su asistente de producción
deja al descubierto lo superficial de su postura: «Entonces, ¿los españoles hablan en
español, pero los taínos que encontró Colón hablan quechua?». En esta escena, la
presencia de la asistente de dirección y sus preguntas inquisitivas están destinadas a
establecer un elemento importante con respecto a la recreación de hechos pasados: Bollaín y su equipo interpretan eventos del pasado (tanto lejanos como recientes); y
es el estudio de los personajes, sus diálogos y acciones una de las formas de poner
al descubierto lo que directora y guionista tienen para decir sobre aquello que
representan. Sirva de ejemplo la descripción y el análisis del diálogo de la siguiente
escena. Camino a la selva, donde van a hacer algunas tomas para la película, la asistente
de producción le pregunta a Sebastián sobre su lugar de filmación, puesto que parece
no tener sentido: están en Bolivia, a 2500 metros sobre el nivel del mar, entre las
montañas y a miles de quilómetros del Caribe (lugar de la llegada de Colón y ambiente
lógico de la historia que quieren contar). El responsable de esa situación es Costa, quien
explica que «esto está lleno de indígenas hambrientos y eso significa extras, miles de
extras. Nada de recurrir a esa mierda de efectos digitales, quiero poderío, que se vea
que nos hemos gastado la pasta». Sebastián le dice que esto podría ser un gran
problema, porque los rasgos de sus actores quechuas son muy distintos a los indios
taínos del guión de su película: ¿qué hace Colón entrevistándose con indígenas de los
Andes? Pero para Costa, son indígenas, sean de donde sean ya que «son todos iguales».
Si Sebastián hubiese aceptado inversores estadounidenses, otro sería el presupuesto y
el lugar de filmación, pero ya que no lo hizo, deberán conformarse con Bolivia. Para
Sebastián hacer una obra donde los españoles hablasen en inglés era una aberración
porque «los españoles hablan en español». La respuesta de su asistente de producción
deja al descubierto lo superficial de su postura: «Entonces, ¿los españoles hablan en
español, pero los taínos que encontró Colón hablan quechua?». En esta escena, la
presencia de la asistente de dirección y sus preguntas inquisitivas están destinadas a
establecer un elemento importante con respecto a la recreación de hechos pasados: Bollaín y su equipo interpretan eventos del pasado (tanto lejanos como recientes); y
es el estudio de los personajes, sus diálogos y acciones una de las formas de poner
al descubierto lo que directora y guionista tienen para decir sobre aquello que
representan. Sirva de ejemplo la descripción y el análisis del diálogo de la siguiente
escena. Camino a la selva, donde van a hacer algunas tomas para la película, la asistente
de producción le pregunta a Sebastián sobre su lugar de filmación, puesto que parece
no tener sentido: están en Bolivia, a 2500 metros sobre el nivel del mar, entre las
montañas y a miles de quilómetros del Caribe (lugar de la llegada de Colón y ambiente
lógico de la historia que quieren contar). El responsable de esa situación es Costa, quien
explica que «esto está lleno de indígenas hambrientos y eso significa extras, miles de
extras. Nada de recurrir a esa mierda de efectos digitales, quiero poderío, que se vea
que nos hemos gastado la pasta». Sebastián le dice que esto podría ser un gran
problema, porque los rasgos de sus actores quechuas son muy distintos a los indios
taínos del guión de su película: ¿qué hace Colón entrevistándose con indígenas de los
Andes? Pero para Costa, son indígenas, sean de donde sean ya que «son todos iguales».
Si Sebastián hubiese aceptado inversores estadounidenses, otro sería el presupuesto y
el lugar de filmación, pero ya que no lo hizo, deberán conformarse con Bolivia. Para
Sebastián hacer una obra donde los españoles hablasen en inglés era una aberración
porque «los españoles hablan en español». La respuesta de su asistente de producción
deja al descubierto lo superficial de su postura: «Entonces, ¿los españoles hablan en
español, pero los taínos que encontró Colón hablan quechua?». En esta escena, la
presencia de la asistente de dirección y sus preguntas inquisitivas están destinadas a
establecer un elemento importante con respecto a la recreación de hechos pasados: 
la representación es siempre una construcción y una interpretación de esos hechos. Más aún, la verdad y la fidelidad absolutas para con la Historia no existen y son también construcciones que implican decisiones de aquel que las enuncia. Así, mediante este diálogo (que parece sencillo pero no lo es), Bollaín puede criticar la representación tradicional verosímil del cine clásico, mientras que propone otra forma de filmar y de interpretar la historia.

El resto de los elementos que hacen a la historia y que están dentro del cuadro de Sulbarán Piñeiro también se dan en una sintonía dicotómica: tiempo y espacio están sincronizados a partir de pares opuestos. Gracias a la representación de la elaboración de una película dentro de otra película, se pueden manejar dos líneas temporales: aquella que refiere a la llegada de Colón a América, y la que remite a la Guerra del Agua del año 2000. Al mismo tiempo, la construcción de dos espacios bien diferenciados en la selva y en la ciudad permite establecer escenarios diferentes y opuestos que guardan relación con el tiempo escenificado: los conflictos de la Guerra del Agua suceden en la ciudad, mientras que la filmación de las escenas de la llegada de Colón a América se hacen en la selva. Cuando el conflicto inminente de la ciudad llegue a la selva, lo hará a causa del personaje de Daniel, a quien lo persigue la policía en plena filmación. Así, hacia el final de la película los acontecimientos de la Guerra del Agua se harán mas urgentes y la violencia presente subsumirá la representación de la violencia del pasado.

El tema del film también se presenta una situación dual (que responde a la presencia de dos tiempos y dos escenarios en una misma historia), aunque no opuesta, ya que el tema de la explotación (de los conquistadores hacia los taínos y de los extranjeros hacia los quechuas bolivianos) parece repetirse y sostenerse, sin importar el escenario o la temporalidad. Así, las escenas de la película de Sebastián no hacen más que espejar la expoliación de los indios tainos por parte de los colonizadores en el siglo xV con el abuso que sufren los quechuas cochabambinos en el siglo xxI (por parte de las compañías extranjeras que quieren cobrar el agua, pero también por parte del equipo técnico de filmación, que les paga apenas dos dólares a sus extras indígenas).

Esto se ve especialmente en el ensayo y filmación de partes del guión de Sebastián que muestran la relación entre españoles y taínos en siglo xv. Tal es el caso de la escena del sermón de Montesinos y Bartolomé de las Casas: los actores que hacen de sendos personajes practican la escena del discurso de Montesinos con el director Sebastián, mientras los trabajadores quechuas construyen la escenografía en plena selva. Les piden que dejen de trabajar diez minutos para que cese el ruido, entonces, todos los indígenas pueden escuchar al actor Juan en la piel de Montesinos recitar:

Los indios están extrayendo el oro con el que construimos nuestras ciudades incluso nuestras iglesias. Un oro que sirve para financiar nuestras conquistas en lugares remotos y hace girar la inmensa rueda del comercio. A todos los alcanza el sudor de los indios, y a los que más a Su Majestad y a sus obispos. Como sacerdote que soy me debo a los mandamientos del Evangelio y el primero de ellos es predicar la verdad: yo soy la voz de Cristo en el desierto de esta isla y estáis en pecado mortal. ¿Con qué derecho les tenéis así de oprimidos y de hambrientos? Se están muriendo por vuestra culpa. Mejor dicho, les matáis.

32 Aquí, con unas pocas imágenes y palabras Bollaín puede mostrar el etnocentrismo español de la conquista fundiéndose perfectamente con la sensación de superioridad de los españoles hacia los bolivianos en pleno comienzo del siglo xxI. Después de todo, las compañías extranjeras en Cochabamba pretenden «hacer girar la rueda del comercio» cobrando un recurso natural tan básico como el agua, dejando como consecuencia una 
enorme cantidad de indígenas «oprimidos y hambrientos». Aunque no lo quieran, Costa y el equipo de filmación se suman a esta situación opresiva ya que intentan abaratar sus costos explotando a los quechuas.

Como último elemento parte de la historia debemos mencionar el conflicto -que está conformado gracias a los personajes, sus acciones, sus objetivos puestos en marcha en un espacio y tiempo determinados. En la película el conflicto se resume en el personaje de Hatuey, actuado por Daniel. Este es en sí mismo una figura que exuda rebeldía en toda la película: desde que protesta en el casting por la discriminación que sufren algunos hasta que toma el control de la revuelta en la plaza, poniendo en peligro la realización del largometraje. Es su accionar, por lo pronto siempre comprometido, siempre constante, el que une las dos puntas de esta historia espejada: modifica la relación opuesta entre los personajes de Sebastián y de Costa y sus acciones, mientras que une la recreación de los hechos pasados con el presente, al ser el líder de dos revueltas: la taína representada en la película de Sebastián, y la quechua en la Guerra del Agua.

En el rodaje del encuentro de Colón con los taínos, éste le dice a un Hatuey rebelde que lo increpa preguntando qué sucedería si ellos no obedeciesen: «Sino, os haremos esclavos, dispondremos de vosotros a voluntad, nos apropiaremos de vuestras posesiones, y os causaremos tanto dolor como podamos». Basta reinterpretar esta respuesta en clave actual y pensar que en el año 2000 esas posesiones ya no están representadas por el oro, sino por el agua, para entender cómo Bollaín tiende ese puente entre hechos lejanos y recientes, para mostrarnos una reflexión del pasado muy actual.

\section{Palabras finales}

La obra tiene numerosos niveles de análisis y mucho más podría escribirse sobre ella. En especial, es una reflexión profunda hacia el accionar actual de los españoles (del año 2010) frente a lo que sucede en América Latina, y que ellos, como parte de una nación imperialista primero y luego como miembros de un primer mundo opresor contribuyeron a crear. Volviendo a la definición de cine histórico que planteábamos al principio, Nogales Cárdenas apunta adecuadamente que «a través de los films también podemos aprender qué imagen o qué idea se tiene de ese pasado en determinados períodos históricos» (2004: 71). Si algo queda claro en También la lluvia desde el primer momento es que la idea del pasado que se plantea (ya hablemos del pasado lejano o reciente) es conflictiva, no clausurada y bastante crítica. Y aquí debemos hacer una salvedad, porque Sabine Schlickers (2015: 119) da cuenta en su libro que la multi premiada obra española tuvo varios cuestionamientos, sobre todo de estudiosos que hicieron observaciones hacia la visión paternalista, externa y unidimensional que el film adopta hacia los quechuas, ya que siempre se ve el punto de vista español y nunca el propio. Al respecto nos hacemos eco de las observaciones de la propia Schlickers (ibíd.), que explica que representar esta perspectiva indígena hubiese sido una imposición por parte de la propia Bollaín; después de todo lo que ha mostrado en el audiovisual es la visión de los dominadores, al tiempo que la critica.

Esto nos lleva a pensar la auto reflexión que directora y guionista presentan en la figura del cineasta Sebastián y en su imperativo de contar-lo-que-pasó y ser ante todo fiel a la verdad. Robert Burgoyne plantea que «en la recreación del pasado, el film histórico 
emplea una variedad de técnicas para producir un elevado sentido de la fidelidad y verosimilitud, creando una experiencia de inmersión poderosa para el espectador ${ }^{12}$ (2007: 552). La recreación en este sentido implica una imaginación del pasado, un repensarlo, no sólo revivir la experiencia. Es la búsqueda de esta fidelidad con la Historia (con H mayúscula) que lleva al cineasta Sebastián a zambullirse en el guión de su película; mientras que la presencia de los indígenas y su entorno (aunque sean quechuas en vez de taínos y esté en la selva boliviana en vez del Caribe) lo compele a imaginar, repensar y revivir ese pasado hasta el punto de perder el sentido de la realidad apremiante que lo rodea. Así, deja de ser la persona aparentemente comprometida del comienzo de la película para convertirse en un extranjero absolutamente egocéntrico.

Elisenda Ardévol Piera, al hablar del cine reflexivo, lo define como aquél que puede reflejar el proceso de producción en el producto. Para ella, reflexividad significa «pensar sobre el pensar, filmar sobre el filmar, mirar como miramos» (2010:144). Si bien lo plantea para el cine etnográfico, es interesante poder aplicarlo al film de Bollaín, porque en definitiva, lo que la directora pretende es mostrar un proceso de filmación en su película (no el de su propio film, pero sí el del personaje del director). Al evocar esta acción reflexiva, Bollaín muestra cierto involucramiento en la situación boliviana actual, cosa que no es muy común en la filmografía. Al respecto, Rafael de España, cuando estudia la forma en la que el cine (español e internacional) abordó la representación de llegada de los españoles a América señala un problema fundamental: en general la filmografía muestra una gran sensibilidad frente a la expoliación indígena por parte de los europeos hace 500 años, pero en ella pocas veces se da cuenta de la situación de explotación actual (1992: 189). Podríamos decir, como lo hicimos antes con la figura de Colón, que el director Sebastián representa a esta filmografía tradicional, que pretende dar cuenta del abuso del pasado, pero que poco quiere hacer frente a la situación presente. Mientras, el personaje de Costa da cuenta de la reflexividad volcada en la película, cuando siente que su opinión sobre los quechuas estaba errada.

Sin embargo (y quizás retomando parcialmente la crítica de Schlickers que mencionamos en párrafos anteriores), esa reflexividad tiene un límite en la historia de Bollaín: el tiempo que estuvieron los españoles en Cochabamba logró operar cambios en los personajes principales, pero no modificaron en absoluto la situación de los bolivianos, y su involucramiento fue muy superficial, al punto de que abandonaron la ciudad en cuanto encontraron problemas. ¿Qué es lo importante a contar? ¿Lo que pasó hace siglos o lo que está pasando en el momento? ¿Lo importante es lo que aparece en la película o lo que le pasa a la gente mientras la hace? También la lluvia nos plantea que ambas cosas son fundamentales; aunque en definitiva, logre resolver mejor la reflexión crítica sobre la historia y el papel que en ella jugaron los europeos, que sobre el propio presente que pretende rescatar. 


\section{BIBLIOGRAFÍA}

ARDÈVOL PIERA Elisenda (1996), «Representación y cine etnográfico», Quaderns de l'ICA, 10, 125-168.

Aumont Jacques, Bergala Alain, MARIE Michel \& Vernet Marc (2005), Estética del cine. Espacio filmico, montaje, narración, lenguaje, Buenos Aires: Paidós.

BORDWELL David (1996), La narración en el cine de ficción, Barcelona: Paidós.

BURGOYNE Robert (2007), «The Balcony of History», Rethinking History, 11(4), 547-554.

CID JuRAdo Alfredo (2012, septiembre), «El relato fílmico-televisivo en la historia del

Bicentenario», comunicación presentada en el Coloquio Universitario de Análisis

Cinematográfico, Ciudad de México.

CRESPO Flores Carlos (2000), Ecología política, 20, 59-70.

DE EsPAÑA Rafael (1992), «España y América: 500 años de Historia a través del Cine», Film-Historia, 2(3), 189-219.

FERRO Marc (2008), El cine, una visión de la historia, Madrid: Akal.

HUESO Ángel Luis (1991), «Planteamientos historiográficos en el cine histórico», Film-Historia, 1(1), 13-24.

Nigra Fabio (2012), Hollywood y la historia de Estados Unidos. La fórmula estadounidense para contar su pasado, Buenos Aires: Imago Mundi.

Nogales CÁRdenas Pedro (2004), Cine amateur e historia local de Reus (Tesis de doctorado), Universitat Rovira i Virgili, Tarragona, <www.tesisenred.net/bitstream/handle/10803/8609/ Indice.pdf?sequence $=43$ \&isAllowed $=y>(8$ diciembre 2019).

PICCINELli Mariana (2018), «Sobre la intertextualidad en el cine. La parodia como crítica histórica: un estudio de caso», F. Nigra (coord.), Visiones críticas del pasado. Hollywood y el cuestionamiento al sistema en los años sesenta y setenta, Buenos Aires: Imago Mundi, 131-150.

ROSENSTONE Robert (1997), El pasado en imágenes. El desafío del cine a nuestra idea de la historia, Barcelona: Ariel.

Rossi María José (2007), El cine como texto. Hacia una hermenéutica de la imagen-movimiento, Buenos Aires: Topía.

SCHLICKERS Sabine (2015), La conquista imaginaria de América: crónicas, literatura y cine, Frankfurt: Peter Lang.

SORLIN Pierre (1985), Sociología del cine, México: FCE.

SUlBARÁN PIÑEIRo Eugenio (2000), «El análisis del film: entre la semiótica del relato y la narrativa fílmica», Opción: Revista de Ciencias Humanas y Sociales, 16(31), 44-71.

THORNTON Bonnie (2015), «También la lluvia: cómo entendemos nuestras historias a través del cine», Spanish: Student Scholarship \& Creative Works, <https://digitalcommons.augustana.edu/ spanstudent/[...]> (8 diciembre 2019).

WHITE Hayden (2010), Ficción histórica, historia ficcional y realidad histórica, Buenos Aires: Prometeo. 


\section{NOTAS}

1. A mediados de 1999 en Cochabamba se dio la concesión de la distribución de agua a un consorcio privado internacional compuesto por capital británico y español. Al mismo tiempo, y por recomendación del Banco Mundial, se aprobó la Ley de Servicios de Agua Potable y Alcantarillado Sanitario que proponía (entre otras cosas) la no subvención en los servicios básicos. A estos eventos le sucedió la organización del campesinado que, tras el incremento en un $35 \%$ de las tarifas del agua en enero de 2000, participó de numerosas protestas, violentamente reprimidas por la policía. El pico máximo de enfrentamiento se dio en abril, frente a lo cual la empresa privada decidió retirarse de Bolivia. Ver Crespo Flores (2000: 60-61).

2. Cristóbal Colón realizó cuatro viajes a América, desde 1492 a 1504. Sus acciones en el continente y la de quienes lo sucedieron, dieron lugar a un largo y violento proceso de conquista que continuó con la colonización y explotación de Latinoamérica por parte de las coronas española y portuguesa.

3. Las palabras entre comillas son pronunciadas por el director Sebastián en la película. En el resto del texto, todos los diálogos de personajes serán citados de la misma manera, entre comillas.

4. Muchos autores consideran la naturaleza productora y reproductora de ideología del cine. Fabio Nigra (2012: 61-81) establece una interesante relación entre la construcción del conocimiento social y las particularidades ideológicas que conlleva la elaboración de una historia; profundizando así la problemática planteada por Hayden White (2010: 217-227) en relación con la capacidad del cine para transmitir lo que frecuentemente se considera como verdad histórica.

5. El carácter textual de lo cinematográfico es una cuestión en la que no todos los analistas de la imagen están de acuerdo. Aquí nos quedaremos con el planteo de María José Rossi, quien señala que «en la medida en que las imágenes cinematográficas componen un entramado hecho de imágenes movimiento, entran dentro de los confines del universo narrativo, es decir, conforman una textualidad» (2007: 41). Para un planteo más profundo sobre el tema ver Mariana Piccinelli (2018: 133-134).

6. Ángel Luis Hueso (1991), siguiendo los trabajos fundantes de Ferro, Sorlin y Jackson, hace un interesante análisis de los films históricos en relación con los planteamientos historiográficos que, según él, primaron en la historiografía del siglo xx; intentando vincular de esta manera las premisas científicas de la academia con la aparición de determinadas películas.

7. Como dice Cid Jurado, esto sucede en general, con aquellas películas que relatan hechos históricos reconocidos como tales por la «historia oficial» (2012: 3).

8. Según Jacques Aumont son tres instancias diferentes que se pueden distinguir en un texto literario (y por extensión en un texto fílmico). Para él, el relato es el enunciado en su materialidad, el texto narrativo que se encarga de contar la historia y que en el caso del cine comprende imágenes, palabras, escritura, ruidos y música. En cuanto a la narración, está compuesta por las relaciones existentes entre el enunciado y la enunciación, tal y como se pueden leer en el relato. Por último está la historia, que es propiamente el contenido narrativo (2005: 107-113).

9. Para Aumont la instancia narrativa es «el lugar abstracto donde se elaboran las elecciones para la conducción del relato y de la historia, donde juegan los códigos y donde se definen los parámetros de producción del relato fílmico» (2005:110). En ella distingue una instancia narrativa ficticia: aquella interna a la historia y que está explícitamente enunciada por uno o más personajes; de una instancia narrativa real, que generalmente queda afuera del cuadro. Esta última instancia es colectiva, ya que la película es obra de un equipo y requiere de decisiones y acciones asumidas por varias personas (guionista, director, operador, montador) y por ello no se puede analizar más que en función de las huellas dejadas por el texto narrativo.

10. Para un análisis más profundo del cine clásico ver Bordwell (1996, capítulo 9). 
11. Cabe aclarar que aquí analizaremos la historia del film de Bollaín, pero también se podría intentar, como si fuese un juego de muñecas rusas, un examen de la historia de la película de Sebastián, que es parte de la historia de la obra principal.

12. Traducción propia.

\section{RESÚMENES}

En el año 2010 la actriz, directora y guionista ibérica Icíar Bollaín dio a conocer su obra También la lluvia. En ella se cuenta la historia de un cineasta español y su productor, quienes en su intento de filmar una película sobre Cristóbal Colón en América, arriban a Cochabamba (Bolivia) en el preciso momento en el que se desata la Guerra del Agua, entre los meses de enero y abril del año 2000. La elección del lugar, que no tiene nada que ver con las Antillas (donde efectivamente llegaron los primeros barcos europeos), da pie a un interesante debate sobre la conformación del indígena latinoamericano y su representación a lo largo del tiempo.

También la lluvia es una película sobre cómo hacer una película: muestra el proceso de elaboración de una recreación cinematográfica; pero a la vez es una obra que une procesos críticos, violentos y opresivos mediante la narración doble de hechos pasados lejanos y más recientes. La naturaleza compleja de este largometraje permite un análisis múltiple tanto en relación a la forma en la que está construida la historia -o las historias- como al contenido con el que trabaja. Por ello se hace necesario un abordaje interdisciplinario, desde la ciencia histórica puesta en diálogo con la semiótica y la narratología. El análisis partirá entonces desde la narrativa fílmica de la película, para luego estudiar el discurso histórico que se presenta. Esto dará lugar a la discusión sobre cómo se narran hechos pasados a través del cine, y la caracterización de una América Latina del siglo XXI a través de ojos europeos bastante críticos.

En 2010, l'actrice, réalisatrice et scénariste espagnole Icíar Bollaín présentait son œuvre También la lluvia qui relate l'histoire d'un réalisateur de film espagnol et de son producteur qui, en vue de tourner un film sur Christophe Colomb en Amérique, arrivent à Cochabamba (Bolivie) au moment précis où la guerre de l'eau éclate, soit au début de l'année 2000. Le choix du lieu (bien loin des Antilles où ont véritablement accosté les premiers bateaux européens) suscite alors un intéressant débat sur la conformation de l'indigène latino-américain et sa représentation au fil du temps.

Il s'agit d'une part d'un film qui interroge la manière dont un film est réalisé puisque, dès le début, il montre le processus d'élaboration d'une recréation cinématographique et, d'autre part, d'une œuvre qui unit des processus critiques, violents et oppressifs par le biais de la narration double de faits passés anciens et plus récents. La nature complexe de ce long-métrage permet une analyse multiple aussi bien à l'égard de la forme qui étaie l'histoire - ou les histoires - que du contenu à partir duquel il travaille. C'est pourquoi il s'avère indispensable de considérer une approche interdisciplinaire qui permette à la science historique, à la sémiotique et à la narratologie de dialoguer. L'analyse partira donc de la narration filmique pour ensuite étudier le discours historique relayé par le film. Cela nous permettra ainsi d'évoquer la manière dont les faits passés sont narrés par le truchement du cinéma et la représentation d'une Amérique latine $\mathrm{du} \mathrm{XXI}^{\mathrm{e}}$ siècle à travers des yeux européens plutôt critiques. 
In 2010 Iberian actress, director and writer Icíar Bollaín presented her work Tambien la lluvia. The movie tells the story of a filmmaker and his producer, who travel to Cochabamba (Bolivia) in order to shoot the landing of the Spanish conqueror Cristóbal Colon in America. Unfortunately, the crew arrived while in Cochabamba was bursting out the so-called Water War, in January 2000. The controversial choice of the filming location (far from the Antilles, where in fact the first European ships landed) leads to an interesting debate around the conception and representation of Latin American natives.

También la lluvia is a movie that deals with the process of making a movie. Furthermore, the play reunites violent, critical and oppressive situations by the double representation of past events, both remote and recent. The complex nature of this film allows a multiple study, taking into account the content represented but also the way in which the stories are built. Thus, it is necessary to implement an interdisciplinary approach, considering history as well as semiotics and narratology. The analysis will begin with the examination of the movie narrative, to subsequently study the historical discourse represented in it. This will allow us to discuss the recreation of past events in films, and the characterization of a contemporary Latin America from a critical European point of view.

\section{ÍNDICE}

Palabras claves: historia y cine, América Latina, Bolivia, conquista de América, imperialismo, Guerra del Agua

Keywords: cinema and history, Latin America, Bolivia, America's conquest, imperialism, Water War

Mots-clés: histoire et cinéma, Amérique latine, Bolivie, conquête de l'Amérique, impérialisme, guerre de l'eau

\section{AUTOR}

\section{MARIANA PICCINELLI}

Universidad de Buenos Aires

marianapiccinelli@hotmail.com 